\title{
BASIC CHARACTERISTICS OF TRAFFIC ON PRIMARY RURAL ROADS IN SERBIA
}

\author{
Mihailo Maletin ${ }^{1}$, Vladan Tubić ${ }^{2}$ \\ ${ }^{1}$ University of Belgrade, Civil Engineering Faculty, Bulevar kralja Aleksandra 71, 11000 Belgrade, Serbia \\ ${ }^{2}$ University of Belgrade, Faculty of Transport and Traffic Engineering, Vojvode Stepe 305, 11000 Belgrade, Serbia
}

Received 5 September 2013; accepted 30 September 2013

\begin{abstract}
This article presents the results of an overall analysis of traffic demand characteristics on Republic of Serbia primary road network based on available data for the years 1988-2009. The analysis is based on network subdivision in three functional entities and collected data on values of basic parameters as Average Annual Daily Traffic (AADT) and Vehicle Kilometers / Year. Traffic demand changes of international origin, destination and transit trips are of special interest due to the fact that primary rural road network in Serbia accommodates a substantial volume of such road movement. Road sections of Pan European Multimodal Transportation Corridor X in Serbia, actually the trunk roads in Southeast Europe, are analyzed further in order to define demand characteristics and future prospects. Based on the general analysis results conclusions are defined together with recommendations for near future actions.
\end{abstract}

Keywords: primary rural roads in Serbia, road traffic demand, international road traffic, traffic loads, corridor X.

\section{Introduction}

This article presents the results of the overall analyses of road transport demand changes in the 1988-2009 with special emphases on road traffic pattern on primary state roads in the Republic of Serbia. Based on data collected by Public Enterprise Roads of Serbia the specific road database was developed on Faculty of Transport and Traffic Engineering (FTTE, 2010). Republic of Serbia primary road network in 2009 has the total length of 4,770 kilometers; it is divided in 643 sections (average section length $7.41 \mathrm{~km}$ ) with available continuous traffic counting data checked and assigned to appropriate sections. For the purpose of this article, the results of more detailed analyses are summarized.
As defined previously (Maletin and Tubic, 2005; Tubic and Maletin, 2003) the preliminary analyses of road traffic flows data base suggested that the overall analyses of demand on primary state road network of Serbia requires the classification of roads into three functional subgroups: primary rural A-roads, primary rural B-roads and urban sections of primary roads (C-roads). The road database (FTTE, 2010) is updated on yearly basis with new road sections and/or functional subgroups changes thus reflecting the actual state while retaining the consistency of analyses approach.

Analysis of primary rural road network in Serbia has to include road traffic demand changes of origin, destination and especially transit trips since primary rural road network in Serbia accommodates a substantial volume

${ }^{2}$ Corresponding author: vladan@sf.bg.ac.rs 
of such trips. Data on these trips are collected by official statistics and comprise passenger vehicles (SV30, 2002-2009) and freight vehicles (SV31, 2004-2009) crossing the state border of Serbia. Demand changes on road sections of Pan European Transportation Corridor X in Serbia, which accommodate most of transit trips together with intensive internal traffic, are analyzed in some detail in order to define major factors that influence past, present and future traffic flows.

\section{Primary Rural Roads in Serbia}

Primary rural road network in Serbia (or state public roads of first order as defined by the Law on Public Roads) has total length of 4,770.1 kilometers. Previous general analysis (Maletin and Tubic, 2005) suggested its division in three functional subgroups; such an approach is recommended to be officially verified in the process of rural road categorization (Tubic and Maletin, 2008). Three functional subgroups (year 2009) are illustrated on Fig. 1a and described as follows:

- First level primary rural road network (A-roads, 139 sections with total length of $1,326.1 \mathrm{kms}, 27.8 \%$ of primary network length) is composed of rural sections of most important European E-roads on the territory of Republic of Serbia.

- Second level primary rural road network (B-roads, 492 sections with total length of $3,373.1 \mathrm{kms}, 70.7 \%$ of primary network length) composed of the remaining rural sections of primary roads.

- Primary road sections through urban areas (C-roads, 12 urban sections with length of $71.1 \mathrm{kms}, 1.5 \%$ of primary network length) form a specific subgroup; most of these sections are located in Belgrade metropolitan area.

Today on primary A-roads network there are 423.2 kilometers with motorway cross section (Fig. 1b) and 122.1 kilometers of motorway half cross section operating as two way two lane roads (other roadway is under construction); all these sections function with toll collection. On primary B-road network 26.5 kilometers motorway connecting the city of Kragujevac with E-75 motorway is in operation. The rest of primary A-roads sections are two lane roads with two way traffic. 

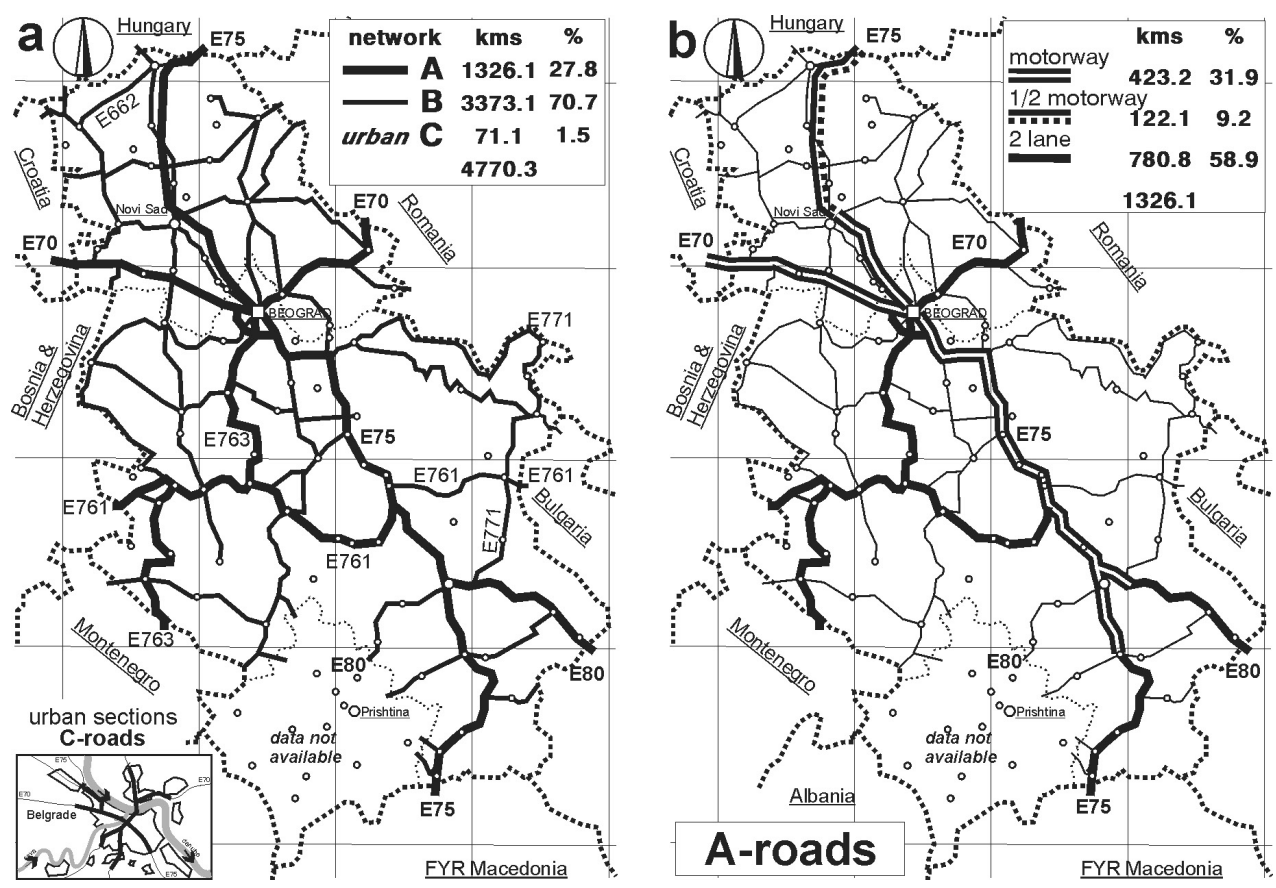

Fig. 1.

Primary Rural Road Network in Serbia: a) Functional Subgroups and b) Types of A-Road Network Sections

Source: FTTE Data Base of Traffic Flows (2010)

\section{Traffic Loads on Primary Roads}

Southeastern Europe region and Republic of Serbia especially experienced substantial and even dramatic changes in virtually all aspects of life between 1990 and 2000. These changes were directly reflected in road traffic demand pattern. Freight and passengers transport demand in all transport modes experienced a dramatic reduction in two years only (1991-1993) while urban public transport followed a specific pattern. From the year 1993, road transport demand remained, more or less, constant at the level of approximately one third of 1975 demand with recovery after year 2000 .

\subsection{Road Traffic Trends}

In the period analyzed (1988 - 2009) vehicle population in Serbia suffered minor changes with motorization rate more or less constant with minimal increase so major impact on road traffic occurred in drastic reduction of yearly vehicle kilometers and substantial increase of vehicle average age. Therefore, forecasting vehicle population in Serbia would be of little value (Jha et al., 2013) in analyzing traffic trends and, due to major presence of transit trips, is not applied in the analyses.

Average Annual Daily Traffic (AADT) is used as the main indicator in trend analysis; it is calculated from continuous count data 
and expressed as section average on network level. Yearly changes of section average AADT are illustrated on Fig. 2. Substantial reduction of road traffic demand due to the external causes are characteristic for 19901993 and 1999 thus reflecting discontinuity of trends. Moreover, it is characteristic that section average AADT value for the base year 1990 is reached in 1997 and 2001 on B-road and $\mathbf{C}$-road sections which accommodate internal long distance and suburban/urban traffic respectively while A-roads sections reached base year 1990 section average AADT value in 2007. Basic problem with A-roads is the slow return of transit trips which will be discussed in following chapters. The presented time series are approximately following the development scenarios (Maletin, 2001), traffic forecasts (Tubic and Maletin, 2002; Tubic and Maletin, 2003) and prospects (Maletin and Tubic, 2002) as defined in 2001 and 2002.

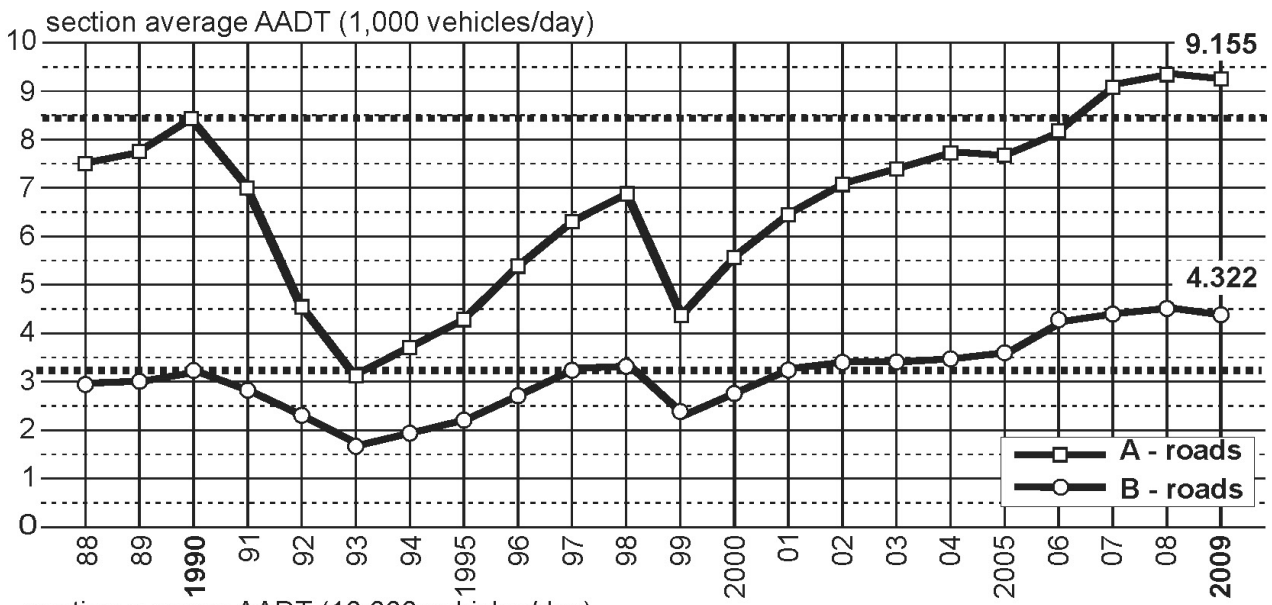

section average AADT (10,000 ve hicles/day)

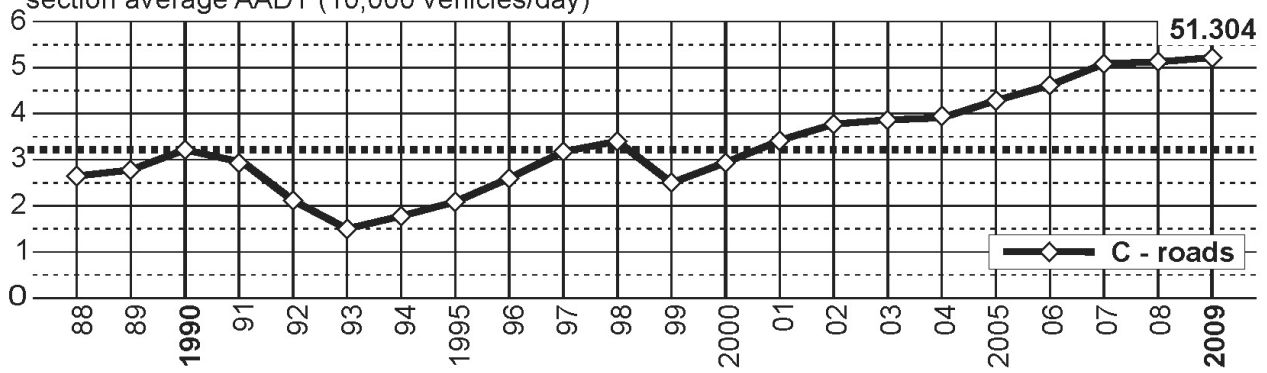

Fig. 2.

Long Term Time Series of Traffic Loads on Functional Subgroups of Primary Roads in Serbia Source: FTTE Data Base of Traffic Flows (2010)

More or less stable trend occurs in the period 2001-2009 with average yearly rate of $4.45 \%$ on A-roads $4.92 \%$ on B-roads and $5.15 \%$ C-roads while negative rates $2009 / 2008$ are recorded on
A and B-roads as the economic crisis reduced long distance road trips. Section average AADT is forecasted by least squares method applied on 2001-2009 time series as presented on Fig. 3. 

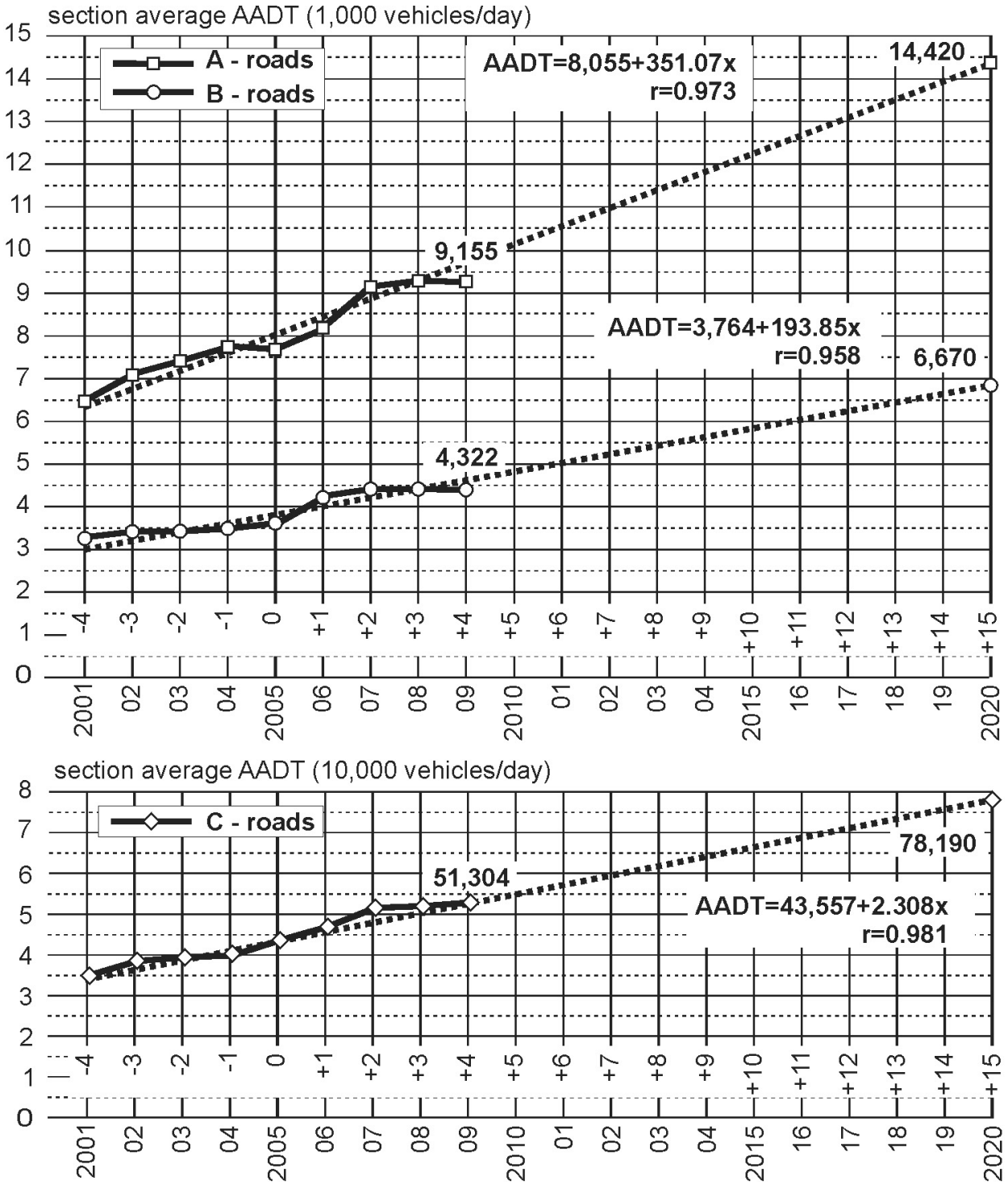

Fig. 3.

Forecasted Section Average AADT for Functional Subgroups of Primary Roads in Serbia Source: FTTE Data Base of Traffic Flows (2010) 
Primary roads vehicle-kilometers yearly total is distributed among functional subgroups (Fig. 4) which leads to general remarks as follows:

- The percentage of sub networks (A, B, C) kilometers in primary roads total length is close to constant in the period analyzed.

- Relative high concentration of vehicle-kilometers occurs on urban sections (C-roads) where $1.5 \%$ of total primary road network length in 2009 accommodates $9.7 \%$ of total vehiclekilometers (in 1990 7.7\%, 2004 9.3\%). Actually, urban sections of primary state roads are accommodating local movements of vehicles in Belgrade metropolitan area due to inadequate public transport supply and poor level of service on other urban roads.

- On primary rural network B with $70.7 \%$ of total primary road network length in $200948.2 \%$ of total vehiclekilometers is accommodated (in 1990 $44.5 \%, 200447.1 \%)$. This subgroup of the primaries should be reclassified since some sections are closely parallel while connecting same origins and

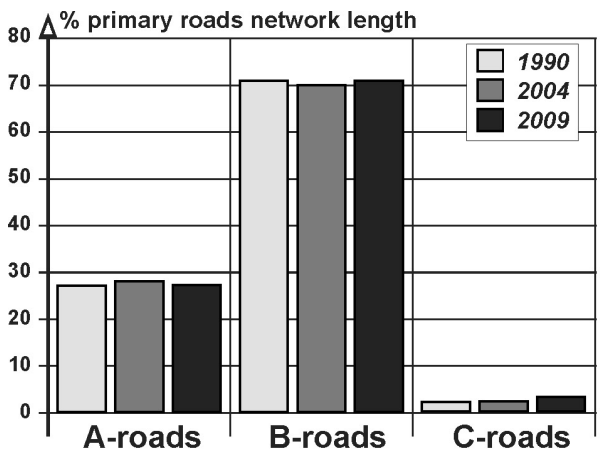

destinations as network $\mathrm{A}$ stretches and in some regions the density of primary roads is substantially higher than the concentration of land uses that generate and attract traffic flows.

- Primary rural road network A with $27.8 \%$ of total length accommodates in $200942.1 \%$ of total vehicle-kilometers which is less than in 1990 (47.7\%) and 2004 (43.6\%). Network A section average AADT shows relatively slow recovery after periods of crises due to the low rate of increase in transit flows and long distance origin-destination or internal movements as well. Most of sections within primary rural road network A experienced major changes in trip purposes after 1990. Long-distance tourist trips with private cars, both transit and origin/destination ones, which caused seasonal peak demand during summer months, are sharply reduced. Visas requirement for cross border trips, long and complicated police and customs control procedures, trip makers concern with security and safety, low national income in Serbia and relatively poor road condition are the major reasons.

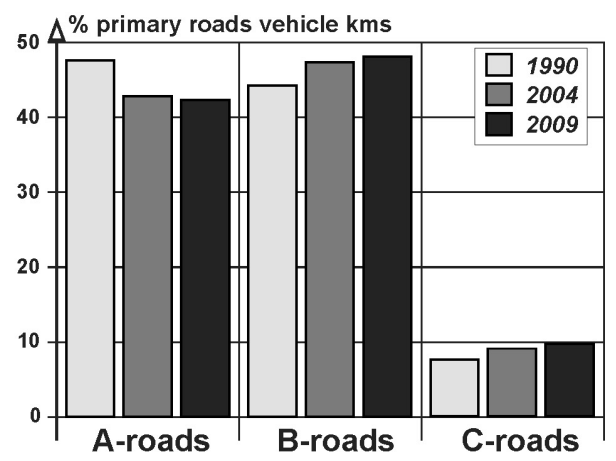

Fig. 4.

Percentage Length and Vehicle Kilometers by Functional Subgroups of Primary Roads in Serbia Source: FTTE Data Base of Traffic Flows (2010) 


\subsection{Traffic Load Classes}

Distribution of rural road sections by classes of traffic loads followed the changes in road transport demand on A and B networks. Comparison of distribution characteristics for 1990, 2004 and 2009 are of special importance (Fig. 5).

On primary rural road network $\mathbf{A}$ in 1990 most sections had traffic loads in the class 7,001-10,000 vehicles/day/both directions with more or less normal distribution (Fig. 5). In $2004,61.3 \%$ section kilometers belonged to 3,001-7,000 class and in 2009 this percentage was $37.6 \%$. It should be added that $21.2 \%$ of existing rural motorways kilometers in 2009 had AADT lower than
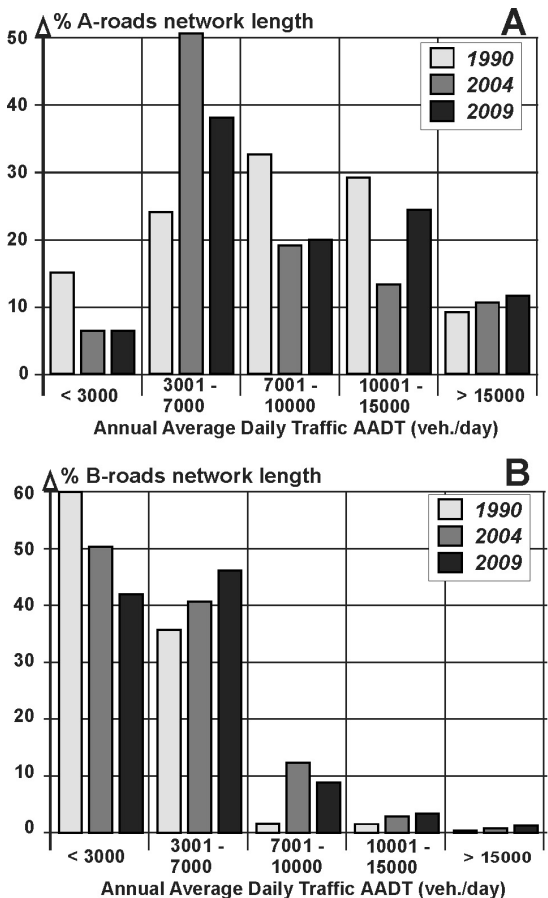

B

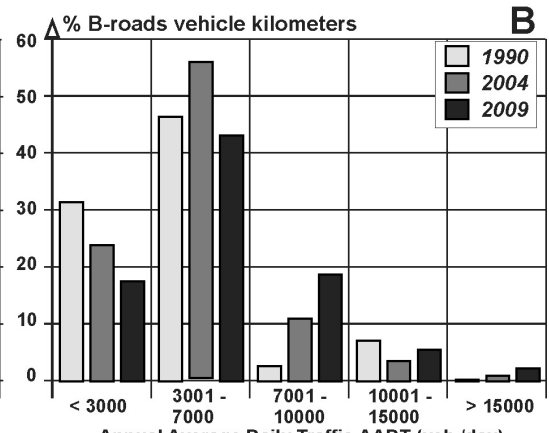

Annual Average Daily Traffic AADT (veh./day)

Fig. 5.

Distribution of Length and Vehicle Kilometers by Traffic Load Classes (AADT) on Primary Rural Road Networks $A$ and $B$

Source: FTTE Data Base of Traffic Flows (2010) 


\section{International Traffic on Primary Rural Roads in Serbia}

According to official statistics data, total transport demand for different transportation modes experienced substantial reduction in 1988-2001 with water and air transport reaching virtually zero demand level in the years of crises (1991-1995, 1999) (Tubic and Maletin, 2002). Major causes for total transport demand reduction were:

- Transit trips through Serbia, both freight and passenger ones, selected other road routes and/or modes of transport.

- Origin and destination trips (O/D) from/to Serbia dropped due to the sharply reduced economic activities and national income in Serbia and international sanctions as well.

- Internal trips followed the same pattern of $\mathrm{O} / \mathrm{D}$ trips with additional influence of national income reduction and extreme fuel shortage during most of the years in the last decade of $20^{\text {th }}$ century.

After the periods of crises (1991-1995, 1999) the road and air transport demand recovered much faster than the demand in water and rail modes and experienced higher rates of increase from year 2000. Nevertheless, road transport demand recovery was highly dependent on the speed with which mentioned causes, international road traffic being the major component, diminished.

\subsection{Passenger Vehicles International Road Traffic}

Data on passenger vehicles (passenger cars and buses) crossing Republic of Serbia border are available from the year 2002 and it could not be compared with base year 1990 . Moreover, the group of foreign registration passenger vehicles was significantly changed after disintegration of Yugoslavia in 1991. Number of passenger vehicles counted entering Serbia is presented on Fig. 6.

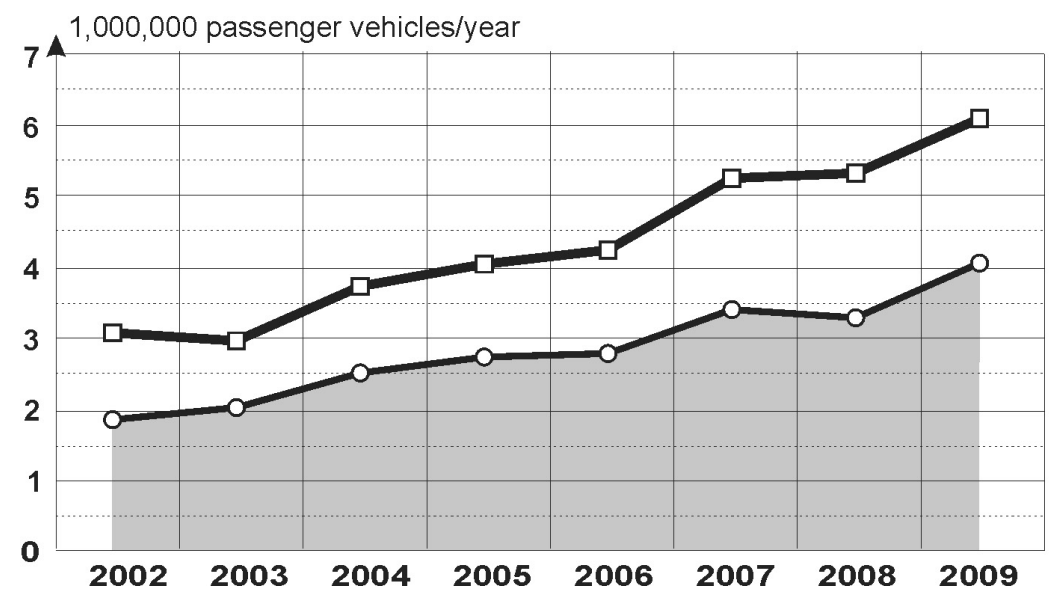

PASSENGER

VEHICLE REGISTRATION

domestic

foreign

Fig. 6.

Passenger Vehicles (Passenger Cars and Buses) Entering Serbia

Source: SV30 (2002-2009) 
Total international passenger vehicles traffic, transit and origin/destination trips, was almost doubled in the period analyzed (2002-2009) with average rate of increase approx. $11 \%$ yearly. Data on passenger vehicles transit is not registered. Foreign registration passenger vehicles are dominant. The highest number of passenger vehicles (Fig. 7) occurs on border crossings with Croatia and Bosnia and Herzegovina with constant and significant yearly rate of increase. Number of passenger vehicles crossing the border with countries of European Union (Hungary, Romania and Bulgaria) is close to constant one at lower level.

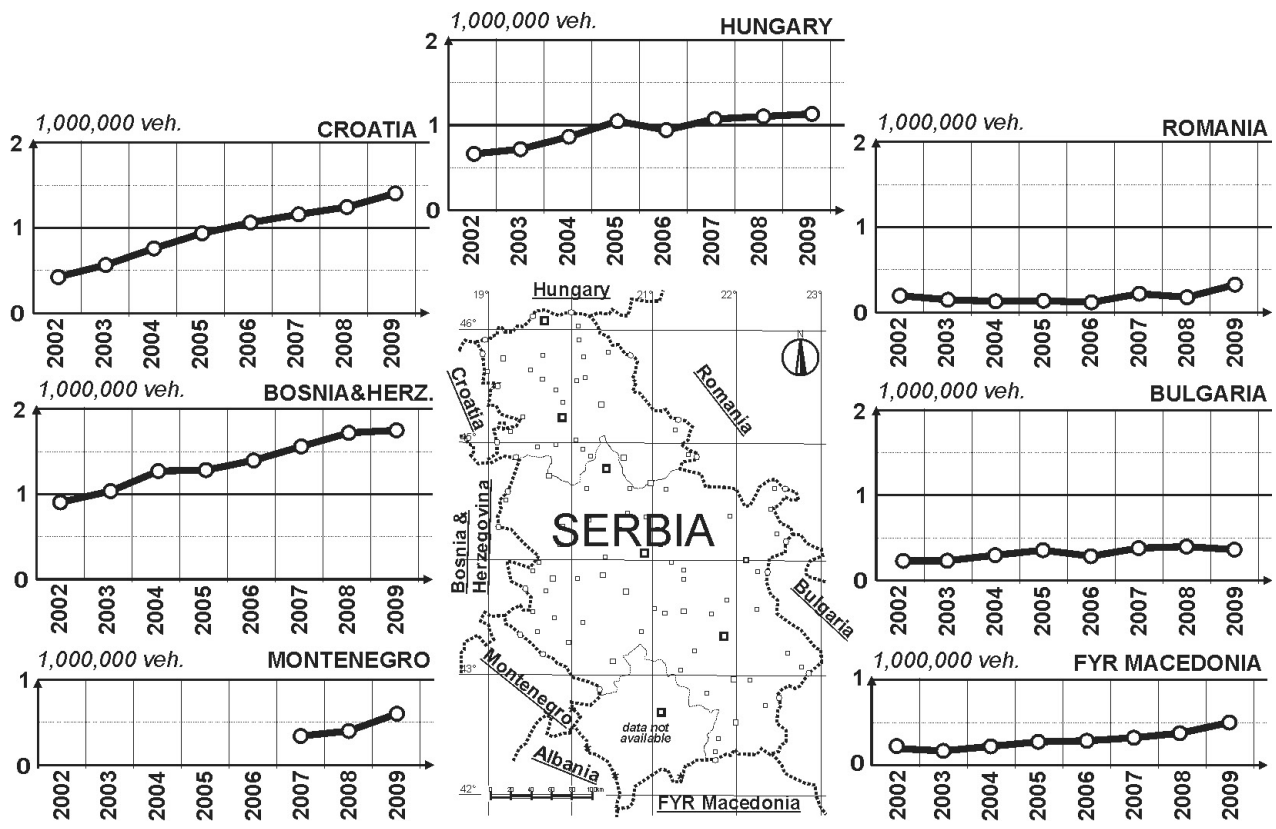

Fig. 7.

Passenger Vehicles (Passenger Cars and Buses) Entering Serbia from Bordering Countries Source: SV30 (2002-2009)

\subsection{Freight Vehicles International Road Traffic}

International road traffic of freight vehicles on Serbia road network collected from year 2004 is divided as destination and transit trips. It should be noticed (Fig. 8) that freight vehicles transiting are more frequent than the ones having destination in Serbia. The sharp decline of freight vehicles transit in 2007 is the consequence of Bulgaria and Romania joining European Union. Further decline in 2009 transit will be discussed in the following chapter. Foreign registration vehicles are dominant in transit $(96.9 \%$ in 2009). 

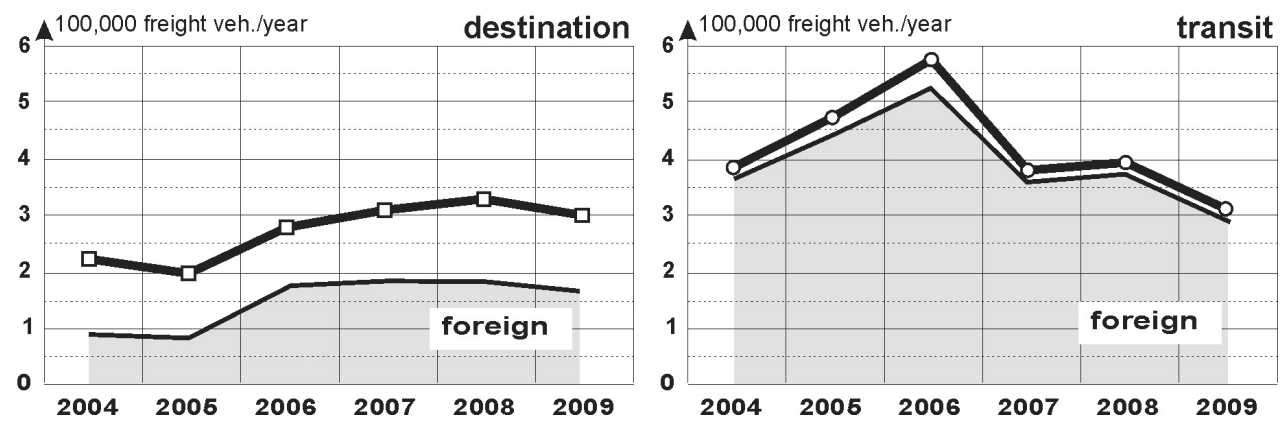

Fig. 8.

Freight Vehicles Destination and Transit Trips on Serbia Road Network

Source: SV31 (2004-2009)

Foreign registration freight vehicles destination and transit trips data presented on Fig. 9 show that six countries with highest percentage are substantially different. Moreover, the number of freight vehicles registered in six countries equals to $73.2 \%$ of destination and $83.0 \%$ of transit trips in Serbia by all foreign registration

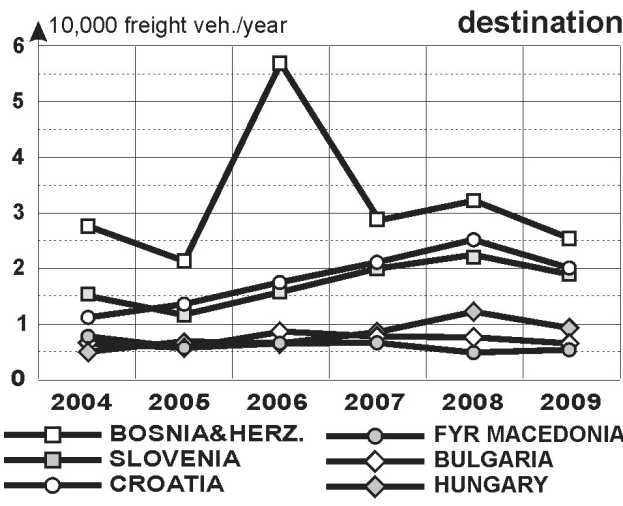

vehicles in 2009. The sharp decline of transit by Bulgarian and Romanian freight vehicles in 2007 explains the decline of total transit trips. The most numerous freight vehicles in transit are the ones registered in Turkey; the reduced number of these vehicles resulted in decline of total transit in 2009.

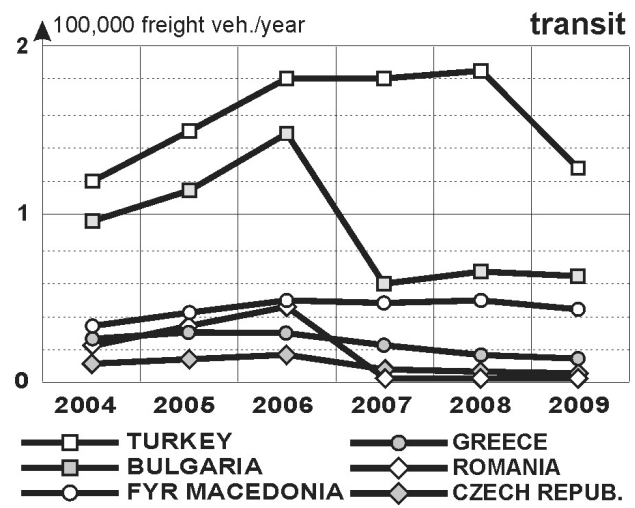

Fig. 9.

Freight Vehicles Destination and Transit Trips on Serbia Road Network by Vehicle Registration Source: SV31 (2004-2009) 


\section{Pan European Corridor X Road Traffic}

Geographical location and major topographical features of Serbia decisively contributed that since the old ages a large proportion of goods and passenger movements were transiting through the area. With the development of rail transport in $19^{\text {th }}$ century and roads in the first half of $20^{\text {th }}$ century the importance of Morava and Vardar rivers valley for the continental and intercontinental trips was continually growing. Several European roads sections (E-roads) are traversing the territory of Serbia and, according to the $3^{\text {rd }}$ Pan European Conference in Helsinki 1997, sections of European multimodal transportation corridors VII (Danube), $\mathrm{X}$ (Munich - Ljubljana - Zagreb - Belgrade Nish - Skopje -Thessalonica, Xb (Budapest - Novi Sad - Belgrade) and Xc (Nish - Sofia) are located on the territory of Republic of Serbia.

Existing motorways (445.4 kilometers including urban sections, four traffic lanes, divided) are the sections of European corridor X (border crossing with Croatia - Belgrade - Nish - Leskovac) and a section of corridor $\mathrm{Xb}$ (Belgrade - Novi Sad). Half motorway (two lane two way with emergency lanes and grade separated intersections) as the first stage of future motorway is built on remaining sections of corridor $\mathrm{Xb}(99.2 \mathrm{~km})$ and Belgrade bypass $(22.9 \mathrm{~km})$. Several sections are under construction either as completion of full motorway (Novi Sad - border with Hungary) or new motorways close to borders of Bulgaria and FYR Macedonia. Most of international transit trips through Serbia use the sections of Pan European corridor $\mathrm{X}$.

Changes of AADT in the 1990-2009 period on road traffic counting locations on corridor $\mathrm{X}, \mathrm{Xb}$ and $\mathrm{Xc}$ close to border crossings are illustrated on Fig. 10. Road sections within corridor $\mathrm{X}, \mathrm{Xb}$ and $\mathrm{Xc}$ experienced dramatic demand changes in periods of crises (19911995, 1999) (Maletin and Tubic, 2002; Tubic, 2006). Even in 2009 AADT on all counting points is much lower than in base year 1990 due to reduction of total international road transport demand and especially in peak summer months of July and August.
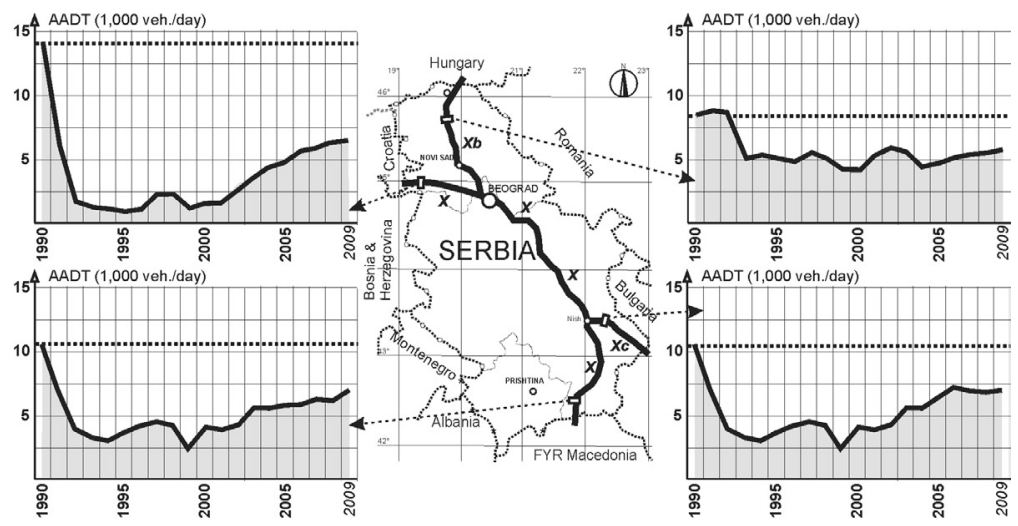

Fig. 10.

Time Series of AADT on Corridor X Sections in Serbia Source: FTTE Data Base of Traffic Flows (2010) 
Although corridor $\mathrm{X}$ roads provide for shortest distance, international transit trips did not return to corridor $\mathrm{X}$ as anticipated since transit passenger and freight flows used, and still are using, less time consuming road routes. Enlarged number of border crossings, duration and procedures of control process, uncertainty of travel time required, etc. are major contributing factors. Introduction of new visa regime (Hungary, Romania and Bulgaria) and development of major motorway sections in South-East Europe are further limiting the possibilities to attract substantial volumes of transit flows to the Republic of Serbia primary A-road network. In that respect, motorway network recent development in Romania, Bulgaria and northern Greece provide total travel time more attractive routes for trips from Middle East, Turkey, Bulgaria and FYR Macedonia to Western Europe.

The most significant changes are registered on corridor X section between Belgrade and border crossing with Croatia (West, corridor $\mathrm{X}, \mathrm{E}-70$ ) and Hungary (North, corridor $\mathrm{Xb}$, E-75). As illustrated on Fig. 11 three periods are characteristic:
- Period I (1990-2000) with extreme reduction of traffic loads on corridor $\mathrm{X}$ (West, Croatia, E-70) and smaller reduction on corridor $\mathrm{Xb}$ (North, Hungary, E-75) due to the redistribution of traffic flows between West and North.

- Period II (2000-2004) with high increase of AADT on corridor X (West, Croatia, E-70); in this period substantial road traffic returned from corridor $\mathrm{Xb}$ sections (North, Hungary, E-75) to corridor X (West, Croatia, E-70)

- Period III (2004-2009) with relatively stable trend on both counting points with substantially higher growth rate on corridor X (West, Croatia, E-70)

Least squares method is applied on time series 2004-2009 for AADT forecast on two counting stations analysed (Fig. 11). Further growth of traffic loads is to be expected both on corridor X (West, Croatia, E-70) and corridor Xb (North, Hungary, E-75) with substantially higher rate of increase of road traffic on the border with Croatia.

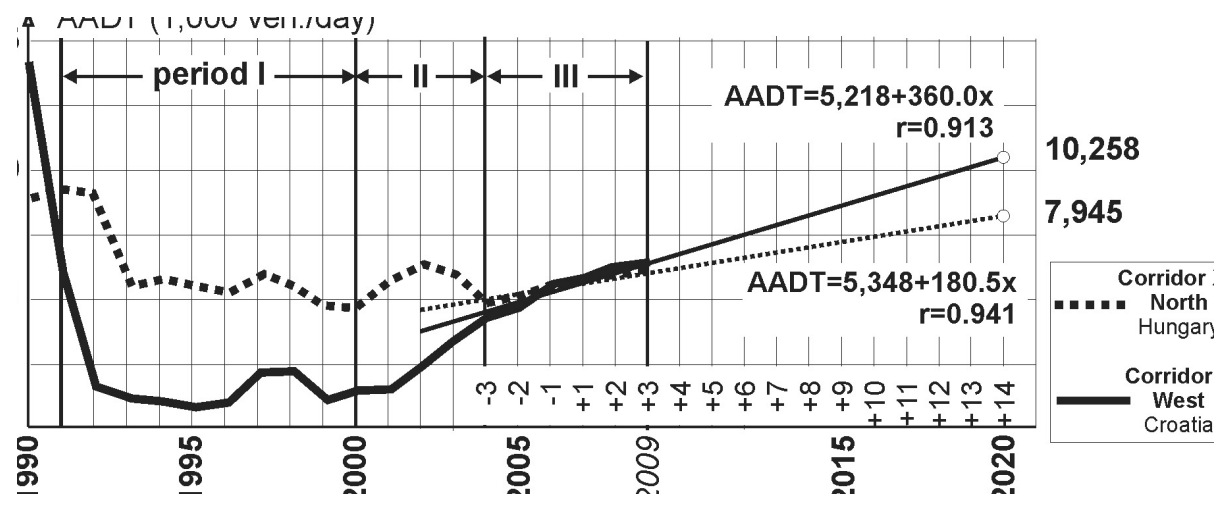

Fig. 11.

Characteristic Periods of Road Traffic Distribution between Corridor X (West, Croatia) and Corridor $\mathrm{Xb}$ (North, Hungary) with AADT Forecasts 


\section{Conclusion}

Based on the results of general analysis of transport demand on primary rural road network in Republic of Serbia following conclusions and recommendations are defined:

- After periods of crises (1991-1995 and 1999) road transport demand on primary roads in Serbia had continuous growth with stagnation and reduction in 2007-2009 due to the economic crisis as a major direct (Serbian economy recession, income reduction etc.) or indirect (reduction of international origin, destination and transit traffic) influence.

- Since traffic loads in 2009 on main international traffic routes (corridor $\mathrm{X}, \mathrm{Xb}$ and $\mathrm{Xc}$ ) are substantially lower than in 1990 the intensive growth of road transport demand for internal transport is a major reason that primary rural road network in Serbia has higher section average AADT than in the base year 1990.

- Stagnation and reduction of freight vehicles international traffic, especially transit one, in last two years of period analyzed should be the major concern of authorities responsible.

- Intensive construction of full motorway on the rest of corridor $\mathrm{X}$ sections in Serbia, although contributing to reversal of the negative trends in international traffic, would not suffice unless priority and coordinated actions on substantial total travel time reduction are not defined and applied. In that respect, cooperation of all states through which corridor X passes and states using it as well, is highly desirable and of mutual benefit.

\section{References}

Faculty of Transport and Traffic Engineering (FTTE). 2010. Data Base of Traffic Flows on Republic of Serbia Rural Road Network 1988-2009, Belgrade, Serbia.

Jha, K.; Sinha, N.; Arkatkar, S.S.; Sarkar, A.K. 2013. Modeling Growth Trend and Forecasting Techniques for Vehicular Population in India, International Journal for Traffic and Transport Engineering. DOI: http://dx.doi. org/10.7708/ijtte.2013.3(2).04, 3(2): 139-158.

Maletin, M. 2001. Development Strategy for Rural Road Network in FR Yugoslavia, International Road Federation. $2^{\text {nd }}$ IRF Road Congress for South-East Europe, Bucharest, Romania.

Maletin, M.; Tubić, V. 2002. Rural Road Network in Republic of Serbia - Present State, Major Problems and Prospects for future. $3^{\text {rd }}$ IRF Road Congress for South-East Europe, Belgrade, Serbia.

Maletin, M.; Tubić, V. 2005. General Analysis of Transportation Demand and Supply on Primary State Rural Road Network in the Republic of Serbia, Transport and Logistics, No. 9: 36-51.

Statistical Office of the Republic of Serbia: Saopstenja SV30. 2002-2009. Belgrade, Serbia.

Statistical Office of the Republic of Serbia: Saopštenja SV31. 2004-2009. Belgrade, Serbia.

Tubić, V. 2006. Analiza saobraćajnih tokova na koridoru $X$, Bezbednost saobraćaja na koridoru X (in Serbian). The Faculty of Transport and Traffic Engineering, Belgrade, Serbia.

Tubić, V.; Maletin, M. 2002. Road Transport Demand Characteristics for the Republic of Serbia - Trends, Present State and Forecast, International Road Federation. $3^{\text {rd }}$ IRF Road Congress for South-East Europe, Belgrade, Serbia. 
Tubić, V.; Maletin, M. 2003. Karakteristike potražnje putnog saobraćaja u Republici Srbiji (in Serbian), Put isaobraćaj, No. 2.

Tubić, V.; Maletin, M. 2008. Kriterijumiza kategorizaciju putne mreže Srbije (in Serbian). The Faculty of Transport and Traffic Engineering, Belgrade, Serbia. 